\title{
MOBILITY OF MERCURY IN THE VOLCANIC/GEOTHERMAL AREA OF NISYROS (GREECE)
}

\author{
Gagliano A.L. ${ }^{1}$, Calabrese S. ${ }^{2}$, Daskalopoulou K. ${ }^{2}$, Cabassi J. ${ }^{3-4}$, Capecchiacci \\ $\mathrm{F}^{3-4}$, Tassi F. ${ }^{3-4}$, Bonsignore M. ${ }^{5}$, Sprovieri M.5, Kyriakopoulos K.6 , Bellomo \\ S. ${ }^{1}$, Brusca L. ${ }^{1}$ and D'Alessandro W. ${ }^{1}$
}

${ }^{1}$ Istituto Nazionale di Geofisica e Vulcanologia, sezione di Palermo, via U. La Malfa 153, 90146, Palermo, Italy, antoninalisa.gagliano@gmail.com,sergio.bellomo@ingv.it, lorenzo.brusca@ingv.it,walter.dalessandro@ingv.it

${ }^{2}$ University of Palermo, Dip. Scienze della Terra e del Mare, via Archirafi 36, 90129, Palermo, Italy,sergio.calabrese@gmail.com, kdaskalopoulou@hotmail.com

${ }^{3-4}$ University of Florence, Dip. Scienze della Terra, and Consiglio Nazionale delle Ricerche, IGG, ViaLa Pira 4, 50121 Florence, Italy, jacopo.cabassi@unifi.it, francesco.capecchiacci@unifi.it, franco.tassi@unifi.it

${ }^{5}$ Consiglio Nazionale delle Ricerche, IAMC, UOS di Capo Granitola, via del Mare 3, 91021, Campobellodi Mazara (TP), Italy,maria.bonsignore@iamc.cnr.it, mario.sprovieri@iamc.cnr.it

${ }^{6}$ National and Kapodistrian University of Athens, Dept. Geology and Geoenvironment, Panestimioupolis, 15784, Ano Ilissia, Greece, ckiriako@geol.uoa.gr

\begin{abstract}
In the summer 2013, mercury concentrations in soils and air from Nisyros (Greece), an active volcanic island located in the Aegean Sea, were determined. Up to 102 samples of soil were collected in the Lakki plain caldera and analyzed for mercury by using a cold vapour atomic absorption analyzer, following 7473 US EPA method. Concentrations of mercury in air were also investigated in the same sites with a portable spectrophotometer (Lumex RA-915M). Soil mercury concentrations were in the range from 0.023 to $13.7 \mu \mathrm{g} / \mathrm{g}$. The mercury concentrations in air showed high background values in the Lakki plain caldera, ranging from 21 to $36 \mathrm{ng} / \mathrm{m}^{3}$ and maximum values up to $493 \mathrm{ng} / \mathrm{m}^{3}$ in the proximity of the fumarolic areas, in contrast with the relatively low values (from 2 to $5 \mathrm{ng} / \mathrm{m}^{3}$ ) measured in the distal sites outside of the caldera. The positive correlation between mercury and $\mathrm{CO}_{2}$ and $\mathrm{H}_{2} \mathrm{~S}$ in the atmosphere highlights the important role of fumarolic gases as carrier for gaseous mercury $\left(\mathrm{Hg}^{\mathrm{O}}\right)$. On the contrary, mercury does not show significant correlations with $\mathrm{CO}_{2}$ and $\mathrm{H}_{2} \mathrm{~S}$ in the soil gases. This finding evidences the complexity of the processes affecting mercury in hydrothermal gases passing through the soil.
\end{abstract}

Keywords: soil mercury, atmospheric mercury, hydrothermal gases, carbon dioxide, hydrogen sulphide.

\section{Пєрі́ $\eta \psi \eta$}

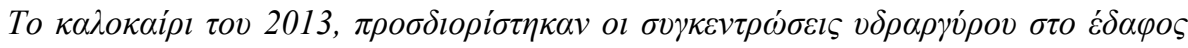

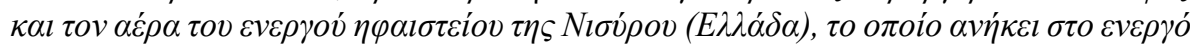

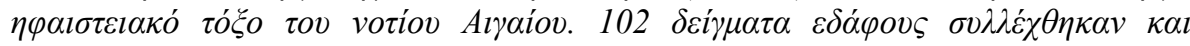




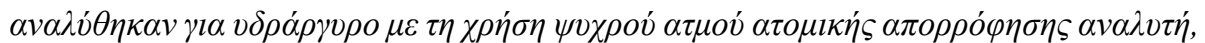

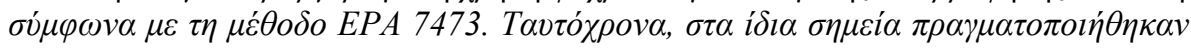

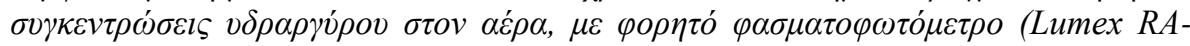

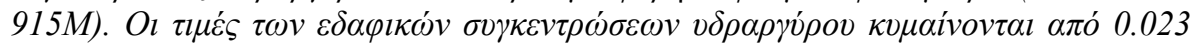

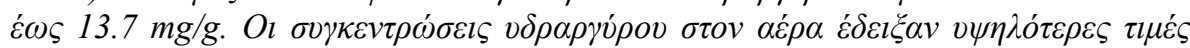

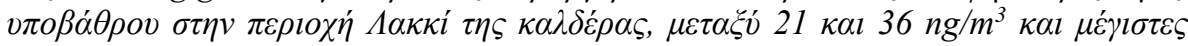

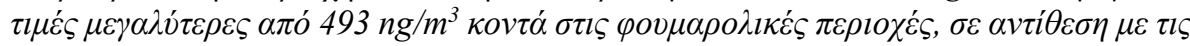

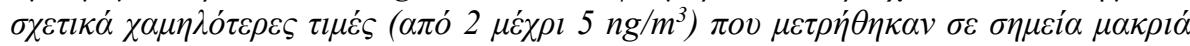

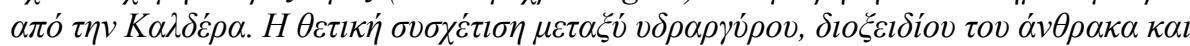

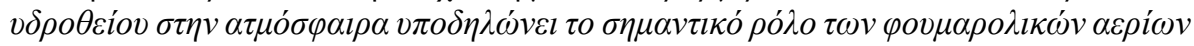

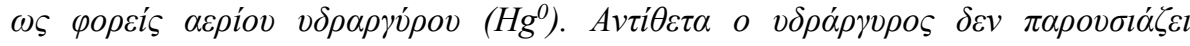

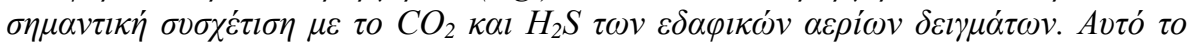

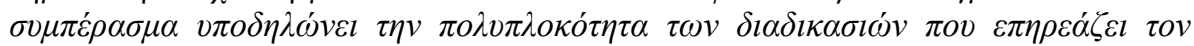

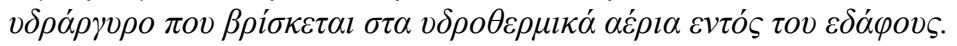

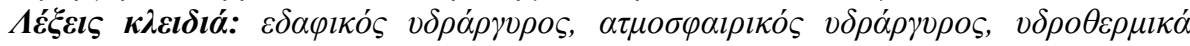

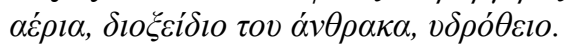

\section{Introduction}

Volcanoes and geothermal areas are natural sources of compounds that are potentially dangerous for the environment and for the human health. High amounts of gases such as of $\mathrm{CO}_{2}, \mathrm{H}_{2} \mathrm{~S}, \mathrm{SO}_{2}, \mathrm{HF}$ and other including gaseous mercury $\left(\mathrm{Hg}^{0}\right)$, are emitted both actively and due to the passive degassing., Trace metals were found at significant concentrations in hydrothermal fluids, being associated with uprising gases. Trace metals even if in very low amount have a significant impact on the biosphere, atmosphere and hydrosphere.

Among the volcanic trace volatile elements, mercury $(\mathrm{Hg})$ is one of the most environmentallysignificant (Mason et al., 1994) because of its extreme mobility and toxicity (Lamborg et al., 2003). The biogeochemistry of $\mathrm{Hg}$ is a highly complex issue due to the exchanges between atmospheric, terrestrial and marine pools (Fitzgerald et al., 1991). These exchanges are mainly driven by microbial activity, dark abiotic and photochemical reactions affecting the $\mathrm{Hg}$ speciation and bioaccumulation (Morel et al., 1998). Mercury is emitted in several forms: elemental (metallic) mercury, inorganic mercury compounds, and organic mercury compounds. Metallic mercury $\left(\mathrm{Hg}^{0}\right)$ is highly volatile due to its high vapour pressure that permits a long-range transport in the air. Monovalent and divalent mercury are soluble in the water; the divalent mercury, $\mathrm{Hg}(\mathrm{II})$, is more stable than monovalent $\mathrm{Hg}(\mathrm{I})$, and common in the environment, it may undergo complexation, precipitation with inorganic ligands, and sorption onto the soil matrix. The toxicological properties of mercury for environment and human health depend on the physical and chemical form in which it occurs. Hg vapors, for example, are very dangerous if inhaled, due to their ability to reach the lungs causing pulmonary edema, pain and peeling of the respiratory epithelium of the bronchi.

Mercury, as constituent of volcanic and geothermal fluid (Barnes and Seward, 1997; Bagnato et al., 2007), is discharged in the water and released into the atmosphere as $\mathrm{Hg}^{0}$ being in association with the reducing non-condensable gases (Nimik et al., 2013; Robertson et al., 1977).

Since in the last decades, authors underlined the correlation in hydrothermal fluid discharged between mercury and hydrogen sulphide (e.g. Vitolo and Saggiani, 2002) related to the formation of solid HgS. Hydrogen sulphide is an odorous pollutant and it is commonly regarded as toxic; it is corrosive and poses severe concerns for human health.

Nisyros Island is a quiescent volcano emitting hydrothermal gases from fumaroles and through soil degassing. Its hydrothermal fluids are particularly rich in $\mathrm{H}_{2} \mathrm{~S}$, causing a low $\mathrm{pH}$ on soils they permeate (Daskalopoulou et al., 2014). The main aim of this work is to calculate the $\mathrm{Hg}$ emitted from the hydrothermal area of Nisyros (Greece) in its gaseous form and measure the concentrations 
of this pollutant in the soil. These results were compared with $\mathrm{H}_{2} \mathrm{~S}$ and $\mathrm{CO}_{2}$ data measured in soil gases and in the air.

\section{Study area}

Nisyros Island is a quiescent volcano located in the easternmost volcanic group of the South Aegean active volcanic arc. The volcanic edifice developed in the last $200 \mathrm{ka}$ through five distinguished stages (Hunziker and Marini, 2005) that led to the formation of a caldera about $4 \mathrm{~km}$ in diameter. The most recent activity is represented by hydrothermal explosions forming several phreatic craters, the last of which occurred in 1887 (Hunziker and Marini, 2005). The Lakki Plain represents the south-eastern remnants of the calderic depression after the emplacement of a series of volcanic domes filling up the north-western part. Fumarolic fields are currently present in this area, mainly within the hydrothermal craters strongly controlled by fracturing along the main NW- and NEtrending active fault systems (Papadopoulos et al., 1998) and are fed by a $>1000 \mathrm{~m}$ deep hydrothermal system having a temperature of $300-350^{\circ} \mathrm{C}$. The fumarolized hydrothermal craters can be subdivided into three main groups: The oldest one comprises the Kaminakia craters, the second consists of the Stephanos crater, whereas the third one corresponds to the youngest area where a post-calderic dome (Lophos) is placed and includes the Phlegeton, Polybotes Megalos and Polybotes Micros craters (Caliro et al., 2005; D'Alessandro et al., 2013). Water vapour (91-99\%) is the main component of the fumarolic fluids, followed by $\mathrm{CO}_{2}$ and $\mathrm{H}_{2} \mathrm{~S}$. The estimated total output of $\mathrm{CO}_{2}$ and $\mathrm{H}_{2} \mathrm{~S}$ is close to $1 \mathrm{~kg} / \mathrm{s}$ and $<0.3 \mathrm{~kg} / \mathrm{s}$, respectively (Caliro et al., 2005; D'Alessandro et al., 2013).

\section{Materials and Methods}

A multidisciplinary field campaign was carried out on June 2013 at Lakki Plain, Nisyros Island, where soil gases and soils were sampled and $\mathrm{Hg}^{0}, \mathrm{H}_{2} \mathrm{~S}$ and $\mathrm{CO}_{2}$ in the air were measured. A total of 102 soil gas samples were collected at Lakki plain mostly in the fumarolic areas of Kaminakia, Stephanos, Micro Polibotes and Phlegeton craters, and in the areas of Ramos and Lophos (Fig. 1).

Gases were sampled at $50 \mathrm{~cm}$ depth using a Teflon tube of $5 \mathrm{~mm}$ ID equipped with a tight plastic syringe to avoid air contamination. The over-pressured vials were used for $\mathrm{H}_{2} \mathrm{~S}$ and $\mathrm{CO}_{2}$ analysis by using Micro Gas Chromatography with a Micro GC MSHA CP-4900 having 3 independent modules.

Ground temperature was measured at $20 \mathrm{~cm}$ depth by using thermal probes and a digital thermometer; these measurements were carried out 10-15 $\mathrm{min}$ after the insertion of the thermal probe in the soil in order to achieve thermal equilibrium.

Soils were collected from the first $3 \mathrm{~cm}$ of depth at 119 spots at Lakki Plain. Soil samples were homogenized and powdered. Homogenized samples were used for the analysis of total $\mathrm{Hg}$, performed using a DMA-80 analyzer (an atomic absorption spectrophotometer, Milestone, Wesleyan University, Middletown, CT, USA). About $10 \mathrm{mg}$ of dry soil were loaded into specific nickel boats and analyzed according to the US-EPA 7473 method. Accuracy was checked by running replicates of the reference materials NCSDC7701 $(0.015 \pm 0.006 \mathrm{mg} / \mathrm{kg})$ and MESS3 $(0.091 \pm 0.009$ $\mathrm{mg} / \mathrm{kg}$ ). Bench quality control material was measured at the start of each analytical run (set of 15 samples) for quality assurance and control. The measured values were, on average, within $\pm 8 \%$ of the recommended values. 

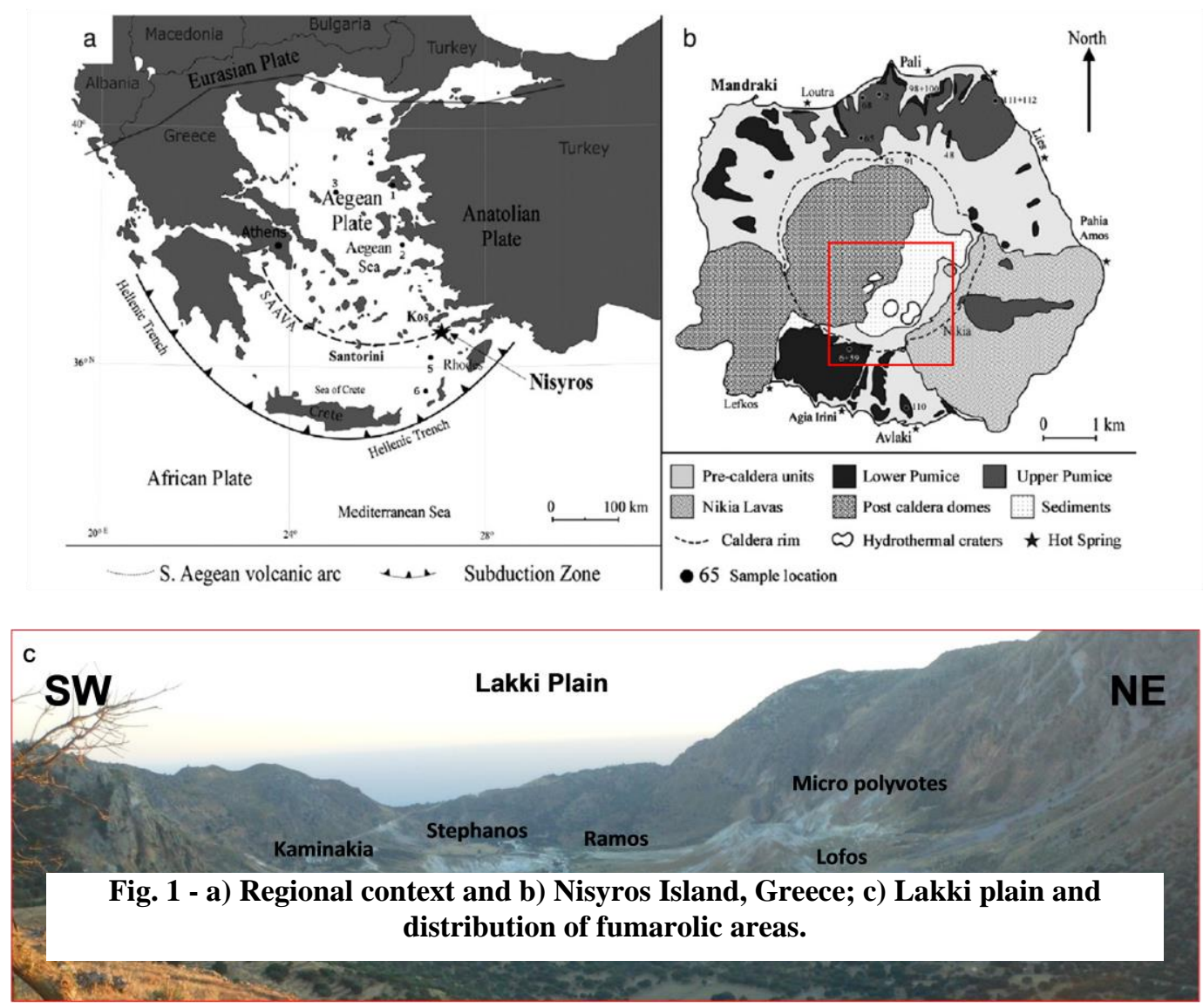

Figure 1 - a) Regional context and b) Nisyros Island, Greece; c) Lakki plain and distribution of fumarolic areas.

The simultaneous real-time measurements of $\mathrm{Hg}^{0}, \mathrm{CO}_{2}, \mathrm{H}_{2} \mathrm{~S}$ and meteorological parameters (air temperature, pressure and relative humidity) were carried out by coupling a portable Zeeman atomic absorption spectrometer with high frequency modulation of light polarization (Lumex RA-915M) and a Multi-GAS analyzer (manufactured by INGV-Palermo). The acquisition of the GPS signal at the same time allowed to obtain spatial coordinates for each concentration value. All instruments were synchronized and set to high-frequency acquisition (every two seconds). Measurements were carried out along three (Kaminakia, Stephanos and Lofos) transects-walk (about $15 \mathrm{~km}$ path, with a mean speed $1.5 \mathrm{~km} / \mathrm{h}$ ) across Lakki plain caldera.

All data were processed by GSA approach (Sinclair, 1974) and plotted by using GIS platform.

\section{Results and Discussion}

\subsection{Soils}

$\mathrm{Hg}$ data in soils, soil gases and real-time measures of $\mathrm{Hg}^{0}, \mathrm{CO}_{2}$ and $\mathrm{H}_{2} \mathrm{~S}$ in the air were integrate to describe, as first step of a deeper study, the behavior of the hydrothermal gases once released and the $\mathrm{Hg}$ transportation processes through the soil and into the atmosphere. 
Soil temperatures provided indication for the hydrothermal uprising gases, allowing to identify the anomalous areas. High temperatures were considered related to high fluxes of hydrothermal fluids and enhanced enrichment of the hydrothermal component in the soil gases. The temperature distribution map at $20 \mathrm{~cm}$ depth indicate temperature above $30^{\circ} \mathrm{C}$ at all the investigated sites, with the exception of some points along the western flank of Kaminakia crater. Higher temperature, in the range of 50 to $100^{\circ} \mathrm{C}$ were recorded at the southern part of Stefanos crater, at Phlegeton and Micro Polibotes (Fig. 2).

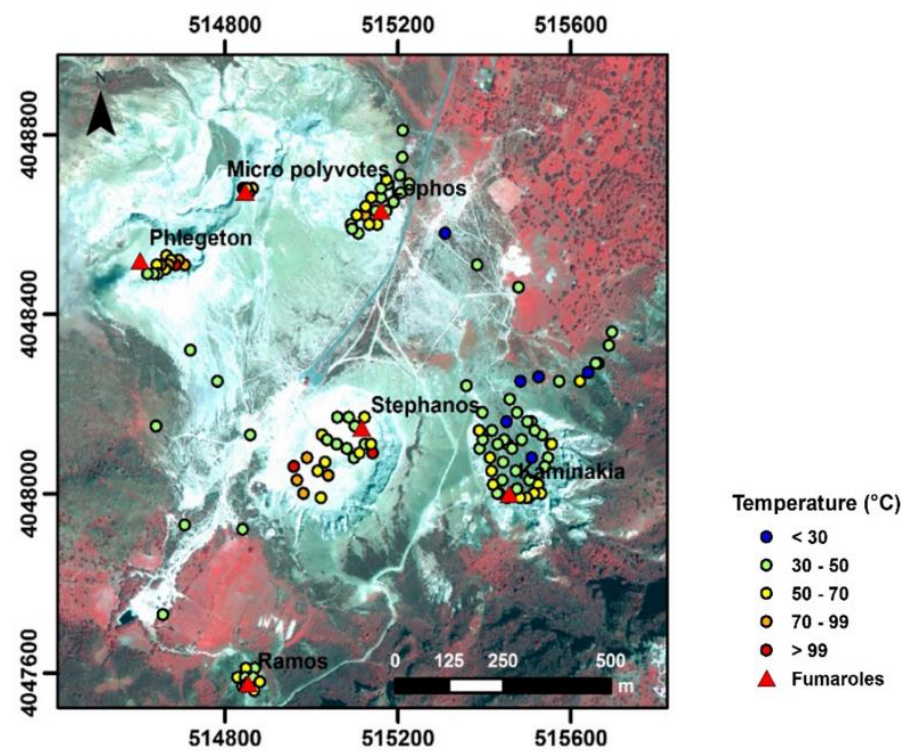

Figure 2 - Temperature distribution at Lakki Plain; temperature measurements were acquired at $20 \mathrm{~cm}$ depth.

The GSA approach (Sinclair, 1974) was applied on the $\mathrm{CO}_{2}$ and $\mathrm{H}_{2} \mathrm{~S}$ dataset and the obtained probability plot allowed to estimate the source of the gas mixture. On the basis of $\mathrm{CO}_{2}$ content, gases can be divided in three main families: background values (close to atmosphere), moderately high values (hydrothermal component and air mixing, $\mathrm{CO}_{2}$ up to $47 \%$ ) and very high values (hydrothermal component, $\mathrm{CO}_{2}$ up to $75 \%$ ) (Fig. 3). The $\mathrm{H}_{2} \mathrm{~S}$ probability plot shows the same three populations, the highest values being up to $18 \%$.
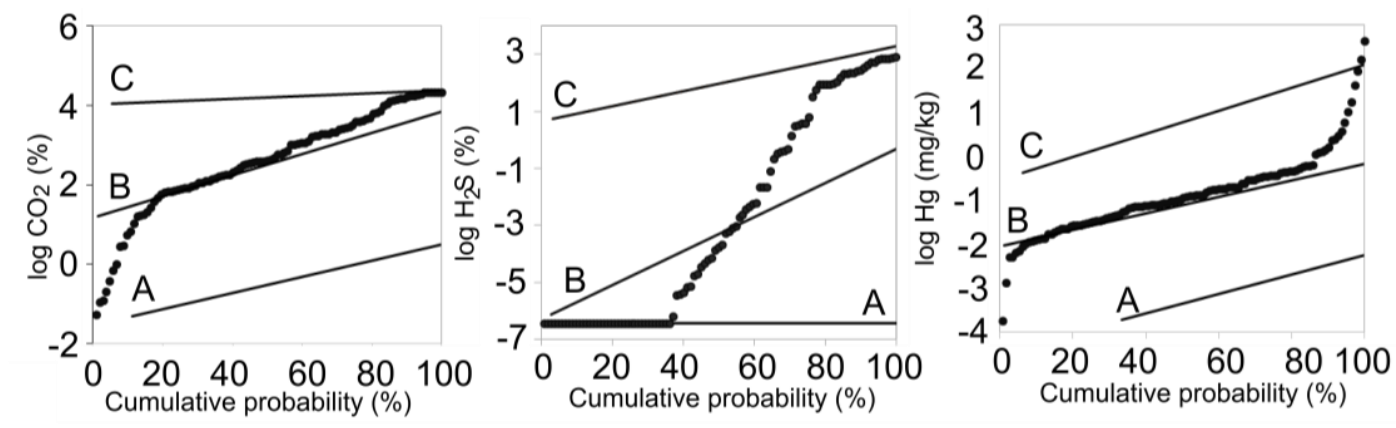

Figure 3 - Probability plots of $\mathrm{CO}_{2}$ and $\mathrm{H}_{2} \mathrm{~S}$ in soil gases and total $\mathrm{Hg}$ in top soils. 

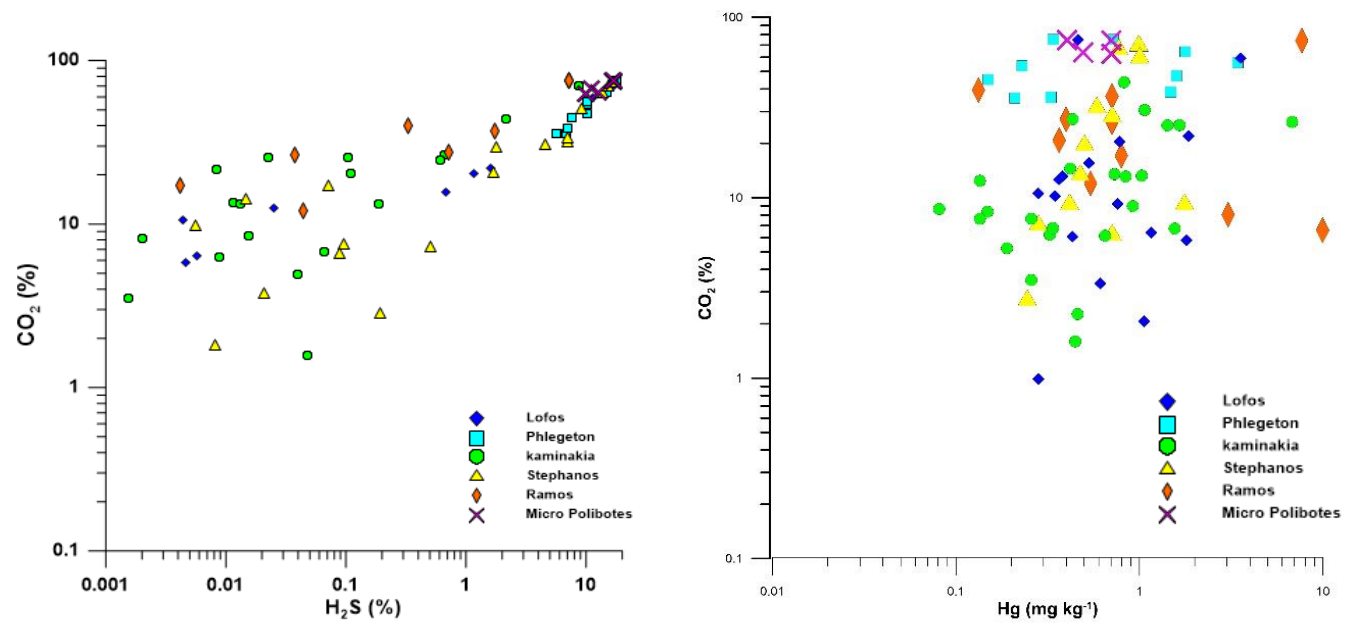

Figure $4-\mathrm{CO}_{2}-\mathrm{H}_{2} \mathrm{~S}$ and $\mathrm{CO}_{2}-\mathrm{Hg}$ binary plots.

The $\mathrm{CO}_{2}$ and $\mathrm{H}_{2} \mathrm{~S}$ contents in the soil gases show a positive correlation, especially at high concentrations (Fig. 4). The general trend indicates that when $\mathrm{CO}_{2}$ values are lower than $30 \%, \mathrm{H}_{2} \mathrm{~S}$ content does not exceed $2 \%$ due to the influence of the diffusive flux. On the contrary, samples with $\mathrm{CO}_{2}$ higher than $30 \%$, show high $\mathrm{H}_{2} \mathrm{~S}$ concentrations, up to $18 \%$, indicating that a convective regime and reducing condition dominate.
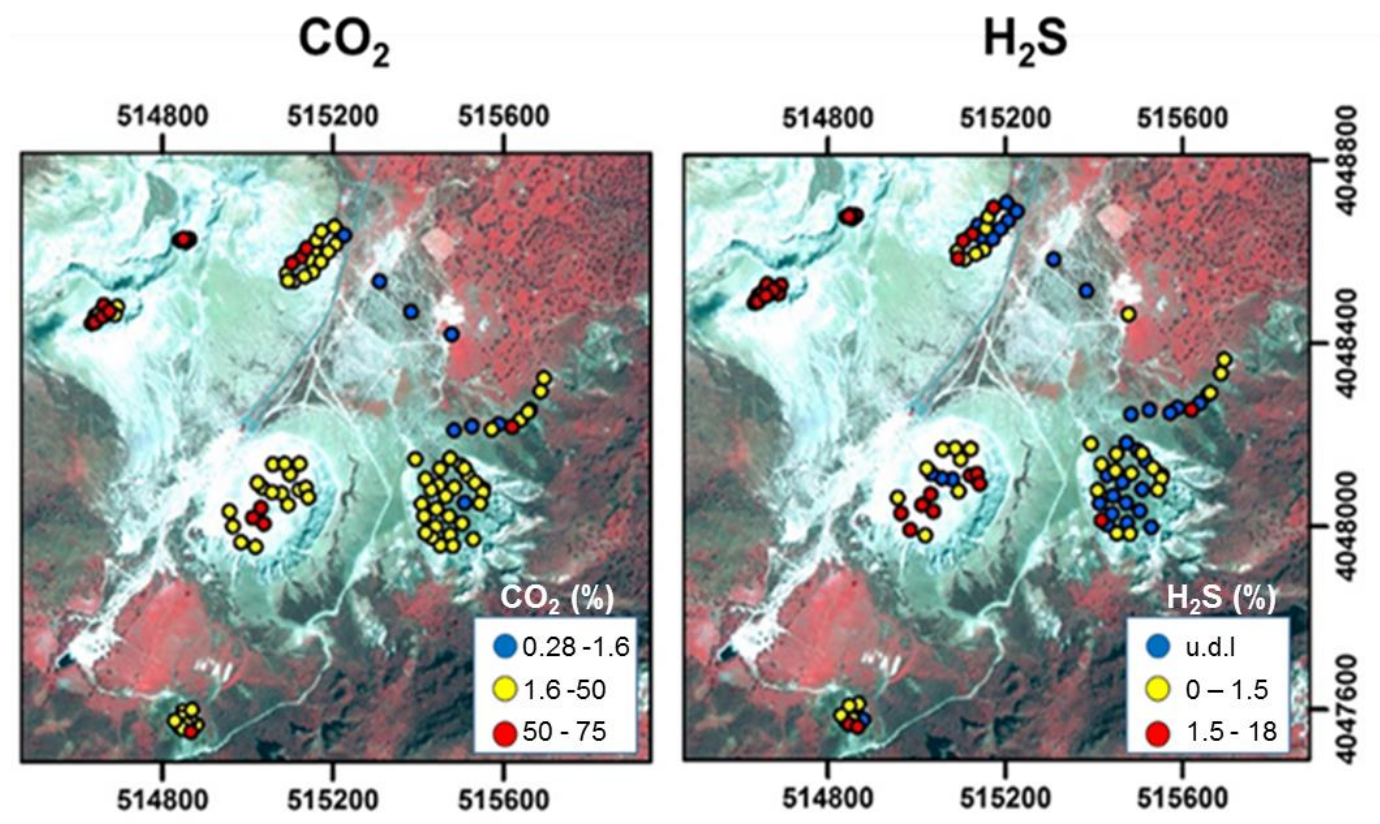

Figure $5-\mathrm{CO}_{2}$ and $\mathrm{H}_{2} \mathrm{~S}$ distribution at the Lakki Plain in soil gases.

High concentrations of $\mathrm{CO}_{2}$ and $\mathrm{H}_{2} \mathrm{~S}$ were measured at Phlegeton and Micro Polyvotes craters (Fig.5), with values close to the fumarolic compositions. Measurements at Lofos and Stefanos 
craters showed variable concentrations of $\mathrm{H}_{2} \mathrm{~S}$ ranging from high concentrations, close to the relative fumarolic composition, down to concentrations below the detection limit.

The distribution of the temperatures and $\mathrm{CO}_{2}$ and $\mathrm{H}_{2} \mathrm{~S}$ concentrations seems to be controlled by the fracturing pattern along the main NW- and NE-trending active fault systems, since the highest values were measured in correspondence of the main fumarolic manifestation, such as in the Stefanos, Micro Polyvotes and Phlegeton craters.

Soils were used to measure the total amount of $\mathrm{Hg}$ trapped in the soils; $\mathrm{Hg}$ value were plotted in a probability plot according to the GSA method and, as for $\mathrm{CO}_{2}$ and $\mathrm{H}_{2} \mathrm{~S}$, three population of data were detected. High $\mathrm{Hg}$ concentrations were also measured at the main fumarolic areas, without showing a clear correlation with $\mathrm{CO}_{2}$ (Fig.4) and $\mathrm{H}_{2} \mathrm{~S}$ (not shown). It is worth noting that all samples have been taken at the same time and in the same place, but $\mathrm{CO}_{2}$ and $\mathrm{H}_{2} \mathrm{~S}$ have been measured on the gas phase collected at $50 \mathrm{~cm}$ depth, while $\mathrm{Hg}$ has been measured on the solid phase at the soil surface. Nevertheless a better correlation was expected. The accumulation of $\mathrm{Hg}$ in the soil matrix does not depend solely on the amount of $\mathrm{Hg}$ carried by the upflowing hydrothermal gases but also on the capability of the soil to fix a part of it. Accumulation of $\mathrm{Hg}$ in soils depends on the amount of complexing phases within the soil. Mercury in soils shows generally a good correlation with soil organic matter (SOM) (Martin et al., 2012 and references therein). The latter, which is the best $\mathrm{Hg}$ sink in the soil, was not determined in the soil samples of Nisyros but it is probably very scarce due to the absence of vegetation in the area. Sulphide, which could react with $\mathrm{Hg}$, is also very scarce in the surface soil levels due to the oxidising environment (Daskalopoulou et al., 2014). Soil temperatures are though to play a role in $\mathrm{Hg}$ retention in soils. This parameter has probably a contrasting effect because higher soil temperatures indicate stronger hydrothermal gases that transport more $\mathrm{Hg}$ from depth, but at the same time higher soil temperatures presuppose also a faster remobilization of $\mathrm{Hg}$ from the soils because of its high volatility (Engle et al., 2006).

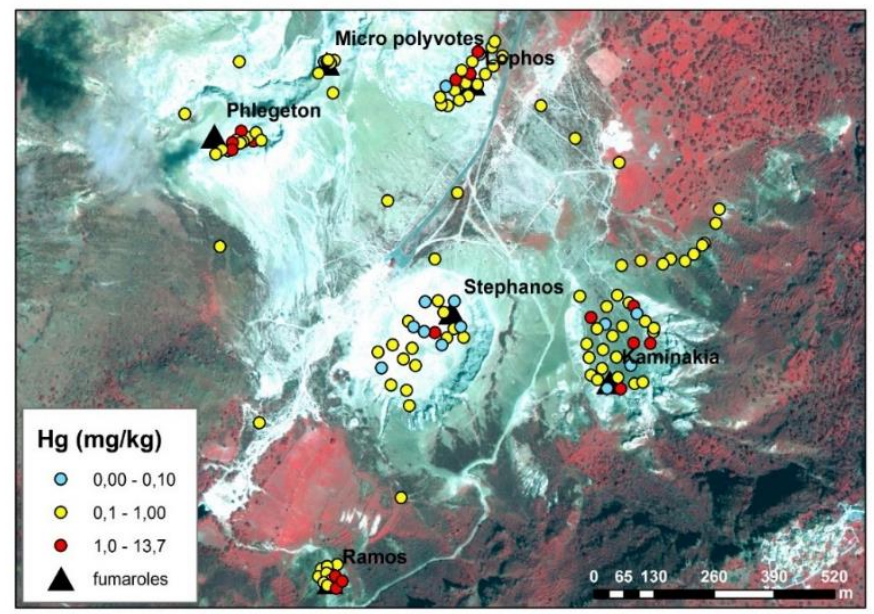

Figure 6 - Total Hg distribution in the top soils of Lakki Plain.

\subsection{Atmosphere}

The data acquired in the atmosphere were processed by using the GSA approach (Sinclair, 1974) and are showed in Figure 7. The $\mathrm{CO}_{2}$ probability plot identifies three main populations (A, B and C). The A population groups value up to $440 \mathrm{ppm}$ and refers to the background atmospheric $\mathrm{CO}_{2}$. Population $\mathrm{B}\left(\mathrm{CO}_{2}\right.$ up to $\left.690 \mathrm{ppm}\right)$ is the population with $\mathrm{CO}_{2}$ level slightly higher than average atmospheric air, probably due to a weak degassing quickly diluted in the air. Population $\mathrm{C}$ includes the highest values (up to $4490 \mathrm{ppm}$ ) indicating a significant fumarolic contribution to the atmosphere. 
Similarly to $\mathrm{CO}_{2}, \mathrm{H}_{2} \mathrm{~S}$ probability plot suggests that the dataset can be divided in three populations; A includes very low $\mathrm{H}_{2} \mathrm{~S}$ concentrations, B values up to $30 \mathrm{ppm}$, indicating a significant $\mathrm{H}_{2} \mathrm{~S}$ emission into the atmosphere, and $\mathrm{C}$ population includes values reaching $63 \mathrm{ppm}$ of $\mathrm{H}_{2} \mathrm{~S}$ in the air, suggesting the significant contribution of the hydrothermal fluids released from the subsurface. Also for $\mathrm{Hg}^{0}$ concentrations in the air, measured with the Lumex instrumentation, three populations were detected (A up to 16.5, B up to 40 and $\mathrm{C}$ up to $490 \mathrm{ng} / \mathrm{m}^{3}$ ).
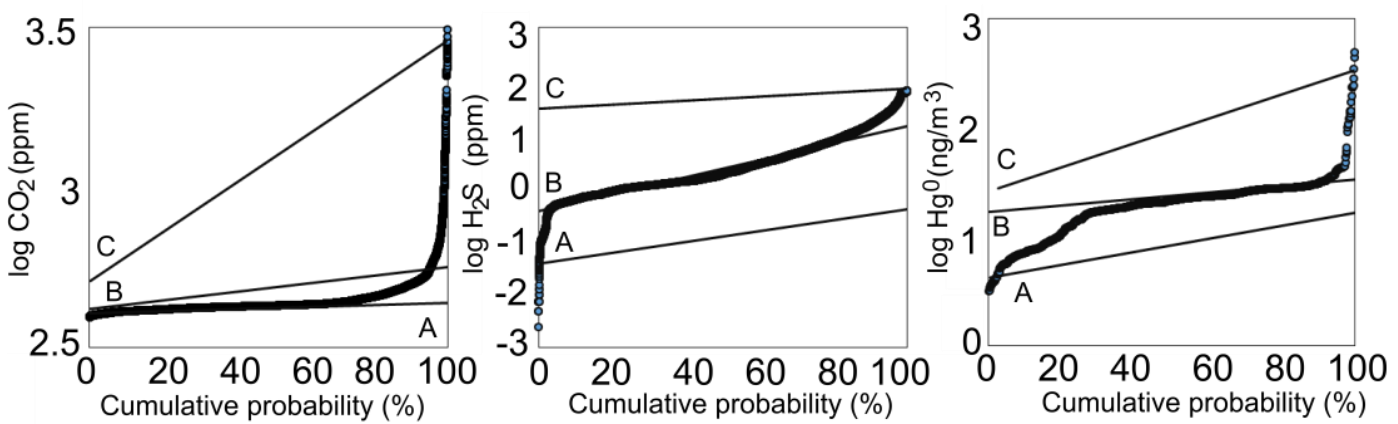

Figure 7 - Probability plots of $\mathrm{CO}_{2}, \mathrm{H}_{2} \mathrm{~S}$ and $\mathrm{Hg}^{0}$ in the atmosphere.

In Fig. 8, atmospheric concentrations of $\mathrm{H}_{2} \mathrm{~S}, \mathrm{CO}_{2}$ and $\mathrm{Hg}^{0}$ against the number of measures over time, carried out through transect walk inside Stefanos crater, are shown. The main fumarolic emissions inside the crater were clearly highlighted by anomalously high $\mathrm{Hg}^{0}$ concentrations (up to $\left.\sim 500 \mathrm{ng} / \mathrm{m}^{3}\right)$ with respect to the surrounding air masses $\left(\sim 30 \mathrm{ng} / \mathrm{m}^{3}\right)$. Part of the released mercury is probably immediately retained within the soil, where it tends to form organo-metallic complexes (e.g. Landa, 1978). A good match between $\mathrm{Hg}^{0}, \mathrm{H}_{2} \mathrm{~S}$ and $\mathrm{CO}_{2}$ concentration peaks was achieved, confirming the interdependence of these gaseous compounds and their common fumarolic origin. The variability in the continuous concentration signal probably depends on: i) different emission mechanisms among the gases, having a direct impact on their atmospheric dispersion (e.g. Witt et al., 2008); ii) the effect of wind direction and intensity; iii) the dilution of the fumarolic plumes; iv) the presence of multiple emission sources, which include both the fumaroles and the crater floor whose soil is characterized by a diffuse release of hydrothermal gases resulting also in the absence of vegetation.

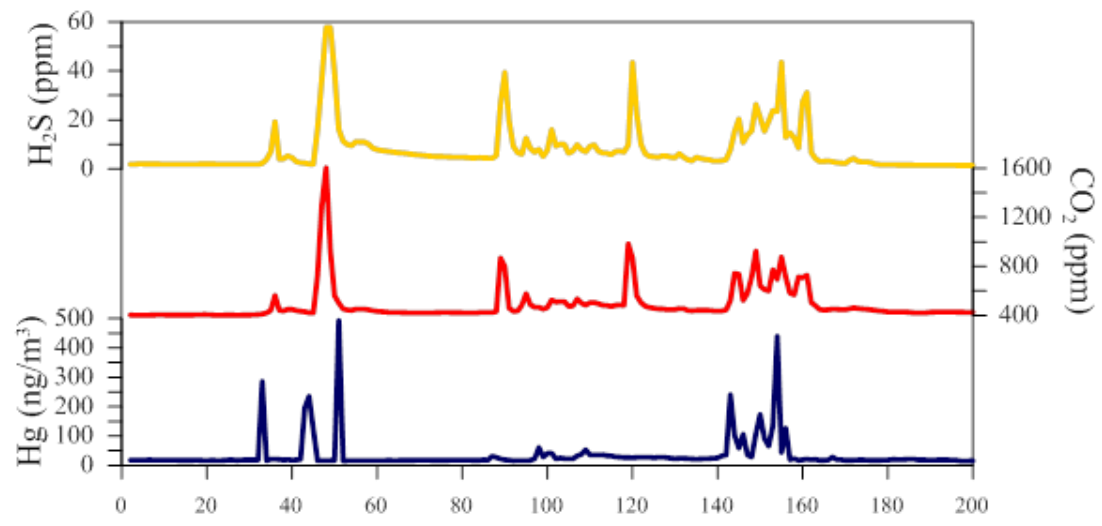

Figure 8 - $\mathrm{CO}_{2}, \mathrm{H}_{2} \mathrm{~S}$ and $\mathrm{Hg}^{0}$ atmospheric concentrations against the number of measures over time within Stefanos crater. 


\section{References}

Bagnato, E., Aiuppa, A., Parello, F., Calabrese, S., D’Alessandro, W., Mather, T.A., McGonigle, A.J.S., Pyle, D.M. and Wängberg, I., 2007. Degassing of gaseous (elemental and reactive) and particulate mercury from Mount Etna volcano (Southern Italy), Atmos. Environ., 41(35), 7377-7388.

Barnes, H.L. and Seward, T.M., 1997. Geothermal systems and mercury deposits. In: Barnes, H.L., ed., Geochemistry of hydrothermal ore deposits (3rd ed.), John Wiley \& Sons, New York, 699-736.

Caliro, S., Chiodini, G., Galluzzo, D., Granieri, D., La Rocca, M., Saccorotti, G. and Ventura, G. 2005. Recent activity of Nisyros volcano (Greece) inferred from structural, geochemical and seismological data, Bull. Volcanol., 67, 358-369.

D’Alessandro, W., Gagliano, A.L., Kyriakopoulos, K. and Parello, F., 2013. Hydrothermal methane fluxes from the soil at Lakki plain (Nisyros, Greece), Proceedings of the $13^{\text {th }}$ International Congress of the Geological Society of Greece, Chania, Crete, Greece, 5-8 September 2013, Bull. Geol. Soc. Greece, 47(3), 1920-1928.

Daskalopoulou, K., Calabrese, S., Milazzo, S., Brusca, L., Bellomo, S., D’Alessandro, W., Kyriakopoulos, K., Tassi, F. and Parello, F., 2014. Trace elements mobility in soils from the hydrothermal area of Nisyros (Greece), Annals Geophys., 57 Fast Track 2, doi: 10.4401/ag6623.

Engle, M.A., Gustin, M., Goff, F., Counce, D.A., Janik, C., Bergfeld, D. and Rytuba, J.J., 2006. Atmospheric mercury emissions from substrates and fumaroles associated with three hydrothermal systems in the western United States, J. Geophys. Res., 111, D17304.

Fitzgerald, W.F., Mason, R.P. and Vandal, G.M., 1991. Atmospheric cycling and air- water exchange of mercury over mid-continental lacustrine regions, Water Air Soil Pollut., 56, 745-767.

Hunziker, J.C. and Marini, L., eds, 2005. The geology, geochemistry and Evolution of Nisyros Volcano (Greece). Implications for the volcanic hazards, Memoires de Geologie (Lausanne), 44, 192.

Lamborg, C.H., Tseng, C.M., Fitzgerald, W.F., Balcom, P.H. and Hammerschmidt, C.R., 2003. Determination of the mercury complexation characteristics of dissolved organic matter in natural waters with "reducible Hg" titrations, Environ. Sci. Technol., 37, 3316-3322.

Landa, E.R., 1978. The retention of metallic mercury vapour by soils, Geochim. Cosmochim. Acta, 42, 1407-1411.

Mason, R.P., Fitzgerald, W.F. and Morel, F.M.M., 1994. The biogeochemical cycling of elemental mercury: anthropogenic influences, Geochim. Cosmochim. Acta, 58(15), 3191-3198.

Morel, F.M.M., Kraepiel, A.M.L. and Amyot, M., 1998. The chemical cycle and bioaccumulation of mercury, Annu. Rev. Ecol. Syst., 29, 543-566.

Nimik, D.A., Caldwell, R.R., Skaar, D.R. and Selch, T.M., 2013. Fate of geothermal mercury from Yelloestone National Park in the Madison and Missouri Rivers, USA, Sci. Total Environ., 4463, 40-54.

Papadopoulos, G.A., Sachpazi, M., Panopoulou, G. and Stavrakakis, G., 1998. The volcanoseismic crisis of the 1996-97 in Nisyros, SE Aegean Sea, Greece, Terra Nova ,10, 151-154.

Park, C.M., Kats, L.E. and Liljestrand, E.M., 2015. Mercury speciation during in situ thermal desorption in soil, J. Haz. Materials, 300, 624-632.

Robertson, D.E, Crecelius, E.A., Fruchter, J.S. and Ludwick, J.D., 1997. Mercury emissions from geothermal power plants, Science, 196, 1094-1097.

Sinclair, A.J., 1974. Selection of threshold values in geochemical data using probability graphs, $J$. Geochem. Explor., 3, 129-149.

Vitolo, S. and Saggiani, M., 2002. Mercury removal from geothermal exhaust gas by sulfurimpregnated and virgin activated carbons, Geothermics, 31, 431-442.

Witt, M.L.I., Fischer, T.P., Pyle, D.M., Yang, T.F. and Zellmer, G.F., 2008. Fumarole compositions and mercury emissions from the Tatun Volcanic field, Taiwan: results from multi-component gas analyser, portable mercury spectrometer and direct sampling techniques, J. Volcanol. Geotherm. Res., 178, 636-643. 